\title{
Improving Indonesian Language Learning Results About Characters and Assignments Through Problem Based Learning Learning Models In SDN 01 Banjaranyar
}

\section{Agus Syukron}

SDN 01 Banjaranyar

Agussyukron8881@gmail.com

\section{Article History}

accepted 14/11/2020

\begin{abstract}
The purpose of this study was to improve the learning outcomes of students in the Indonesian language muple in grade IV elementary schools with the Problem Based Learning (PBL) learning model. The research conducted was a Classroom Action Research (CAR) in two cycles, with each cycle consisting of two meetings. The stages of each cycle are planning, implementing, observing and reflecting. Each meeting is carried out a pre test and post test to determine the progress of students. In the first cycle the students who completed after carrying out the post test were 53\%. In cycle II students who completed after carrying out the post test were $90 \%$. These results indicate that the Problem Based Learning (PBL) learning model can improve the learning outcomes of students, especially Class IV Indonesian language muple at SDN 01 Banjaranyar.
\end{abstract}

Keywords: Problem based learning, Indonesian language, elementary school

\section{Abstrak}

Tujuan dari penelitian ini adalah untuk meningkatkan hasil belajar peserta didik pada mupel Bahasa Indonesia di sekolah dasar kelas IV dengan model pembelajaran Problem Based Learning (PBL). Penelitian yang dilakukan adalah Penelitian Tindakan Kelas (PTK) sebanyak dua siklus, dengan setiap siklusnya terdiri dari dua pertemuan. Tahapan setiap siklusnya adalah perencanaan, pelaksanaan, observasi dan refleksi. Setiap pertemuan dilakukan pre test dan post test untuk mengetahui perkembangan peserta didik. Pada siklus I peserta didik yang tuntas setelah melaksanakan post test sebesar $53 \%$. Pada siklus II peserta didik yang tuntas setelah melaksanakan post test sebesar $90 \%$. Hasil ini menunjukan bahwa model pembelajaran Problem Based Learning (PBL) dapat meningkatkan hasil belajar peserta didik khususnya mupel Bahasa Indonesia Kelas IV di SDN 01 Banjaranyar.

Kata kunci: Problem based learning, bahasa indonesia, sekolah dasar

Social, Humanities, and Education Studies (SHEs): Conference Series https://jurnal.uns.ac.id/shes

p-ISSN 2620-9284

e-ISSN 2620-9292 


\section{PENDAHULUAN}

Menurut Mujiono (1994:31) dalam proses belajar mengajar ada empat komponen penting yang berpengaruh bagi keberhasilan belajar siswa, yaitu bahan belajar, suasana belajar, media dan sumber belajar, serta guru sebagai subyek pembelajaran. Komponen-komponen tersebut sangat penting dalam proses belajar, sehingga melemahnya satu atau lebih komponen dapat menghambat tercapainya tujuan belajar yang optimal.

Penyempurnaan kurikulum adalah salah satu upaya peningkatan mutu pendidikan. Upaya itu berhasil jika ada perubahan pola kegiatan pembelajaran, dari yang berpusat pada guru kepada yang berpusat pada siswa, serta orientasi penilaian dari yang berorientasi diskriminasi siswa kepada yang berorientasi diferensiasi siswa. Keseluruhan perubahan itu akan menentukan hasil pendidikan. Ketepatan penilaian yang dilakukan sekolah, terutama yang berkaitan dengan penilaian kelas, memperlihatkan pencapaian hasil belajar siswa. Penilaian tersebut mempengaruhi pendekatan, kegiatan, dan sumber belajar yang diterapkan guru dalam proses pembelajaran.

Penilaian dan kegiatan pembelajaran bermuara pada penguasaan kompetensi yang diharapkan. Selama ini pelaksanaan penilaian di kelas

kurang mampu menggambarkan kemampuan siswa yang beragam karena cara dan alat yang digunakan kurang sesuai dan kurang bervariasi. Karena keterbatasan kemampuan dan waktu, penilaian cenderung dilakukan dengan menggunakan cara dan alat yang lebih menyederhanakan tuntutan perolehan siswa

Seperti di kelas IV SDN 01 Banjaranyar, pada semseter 1 di ajarkan materi Tokoh dan Penokihan.Namun, masih banyak siswa yang kurang paham terhadap materi tersebut. Hal tersebut dapat terlihat dari hasil belajar siswa yang terbilang rendah. Hal tersebut di sebabkan karena metode pembelajaran di kelas IV masih menggunakan metode konvensional.

Pembelajaran konvensional yang umum dilakukan adalah metode mengajar dalam bentuk ceramah atau informatif, dimana mengajar lebih banyak berbicara dalam menginformasikan fakta atau konsep. Sedangkan siswa hanya mendengarkan dan mencatat saja sehingga hal ini menyebabkan rendahnya minat belajar siswa yang berakibat siswa kurang dapat memahami pelajaran yang disampaikan guru. Tentu saja hal tersebut dapat menyebabkan rendahnya hasil belajar siswa.

Salah satu usaha yang dapat dilakukan untuk meningkatkan hasil belajar siswa pada materi Tokoh dan Penokohan adalah Melalui Model pembelajaran Problem Based Learning. Model pembelajaran Problem Based Learning adalah suatu cara mengajar di mana dalam pembelajaran tersebut dirancang masalah- masalah yang menuntut siswa mendapat pengetahuan yang penting, membuat mereka mahir dalam memecahkan masalah, dan memiliki strategi belajar sendiri serta memiliki kecakapan berpartisipasi dalam tim Model pembelajaran problem based learning (pembelajaran berbasis masalah), awalnya dirancang untuk program graduate bidang kesehatan oleh Barrows, Howard (1986) yang kemudian diadaptasi dalam bidang pendidikan oleh Gallagher (1995). Problem based learning disetting dalam bentuk pembelajaran yang diawali dengan sebuah masalah dengan menggunakan instruktur sebagai pelatihan metakognitif dan diakhiri dengan penyajian dan analisis kerja siswa.

Model pembelajaran problem based learning berlandaskan pada psikologi kognitif, sehingga fokus pengajaran tidak begitu banyak pada apa yang sedang dilakukan siswa, melainkan kepada apa yang sedang mereka pikirkan pada saat mereka melakukan kegiatan itu. Pada problem based learning peran guru lebih berperan sebagai pembimbing dan fasilitator sehingga siswa belajar berpikir dan memecahkan masalah mereka sendiri. Belajar berbasis masalah menemukan akar intelektualnya pada penelitian John Dewey (Ibrahim, 2000). 
Pedagogi Jhon Dewey menganjurkan guru untuk mendorong siswa terlibat dalam proyek atau tugas yang berorientasi masalah dan membentu mereka menyelidiki masalah-masalah tersebut. Pembelajaran yang berdayaguna atau berpusat pada masalah digerakkan oleh keinginan bawaan siswa untuk menyelidiki secara pribadi situasi yang bermakna merupakan hubungan problem based learning dengan psikologi Dewey. Selain Dewey, ahli psikologi Eropa Jean Piaget tokoh pengembang konsep konstruktivisme telah memberikan dukungannya. Pandangan konstruktivisme- kognitif yang didasari atas teori Piaget menyatakan bahwa siswa dalam segala usianya secara aktif terlibat dalam proses perolehan informasi dan membangun pengetahuannya sendiri (Ibrahim,2000).

Berdasarkan permasalahan yang dihadapi dan solusi yang ada, maka perlu dilakukan suatu tindakan berupa penerapan model pembelajaran Problem Based Learning untuk meningkatkan hasil belajar siswa pada materi Tokoh dan Penokohan . Oleh karena itu peneliti tertarik untuk melakukan penelitian yang berjudul "Peningkatan Hasil Belajar Bahasa Indonesia Tentang Tokoh dan Penokohan Melalui Model Pembelajaran Problem Based Learning (PBL) Pada Siswa Kelas IV SDN 01 Banjaranyar Tahun Pelajaran 2020/2021"

\section{METODE}

Penelitian ini adalah penelitian tindakan kelas (Classroom Action Research) dengan menerapkan model pembelajaran Problem Based Learning (PBL). Menurut Kurt Lewin dalam Kunandar (2011: 42) penelitian tindakan kelas ini terdiri dari empat tahapan dasar yaitu perencanaan (planning), pelaksanaan (acting), pengamatan (observing) dan refleksi (reflecting). Analisis penelitian ini adalah analisis deskriptif kuantitafif kualitatif dimana dalam penelitian ini selain penyajian hasil berupa data maupun angka peneliti juga menentukan bagaimana cara pengolahan hasil penelitian yakni dengan membuat analisisnya dengan menerapkan model penelitian Problem Based Learning (PBL). Penelitian ini dilaksanakan pada peserta didik kelas IV SDN 01 Banjaranyar Tahun Pelajaran 2020/2021 selama dua siklus secara daring menggunakan aplikasi Zoom dengan satu pertemuan disetiap siklusnya.. Teknik pengumpulan data yang dilakukan dengan observasi dan tes baik pre test maupun post test. Observasi meliputi observasi keterlaksanaan model pembelajaran PBL, sikap peserta didik dan keterampilan. Untuk hasil belajar menggunakan tes melalui Google form.

\section{HASIL DAN PEMBAHASAN}

Pada bagian pembahasan, diuraikan hasil kajian/penelitian dan hubungannya dengan kerangka teori atau kajian empirik terdahulu. Pada bagian ini dapat mnyertakan tabel dan gambar secara ringkas. Contoh penyajian tabel dan gambar sebagai berikut.

Pada siklus I pembelajaran dilaksanakan selama satu pertemuan, setiap pertemuan diadakan pre test dan post test. Untuk mengetahui perkembangan peserta didik selama pembelajaran. Pembelajaran dengan model PBL dilaksanakan dengan 5 langkah PBL secara berurutan mulai dari Orientasi peserta didik pada masalah, mengorganisasikan peserta didik untuk belajar, membimbing penyelidikan individu maupun kelompok, mengembangkan dan menyajikan hasil karya; dan menganalisis dan mengevaluasi proses pemecahan masalah. Siswa dapat memecahkan masalah dari soal cerita. Berikut ini adalah hasil belajar peserta didik pada siklus I yang bisa dilihat pada tabel berikut. 
Tabel 1. Prestasi Belajar Siklus I

\begin{tabular}{lll}
\hline NILAI & JUMLAH SISWA & PRESENTASE \\
\hline Belum tuntas $<70$ & 8 & $53 \%$ \\
Tuntas $>70$ & 7 & $47 \%$ \\
\hline
\end{tabular}

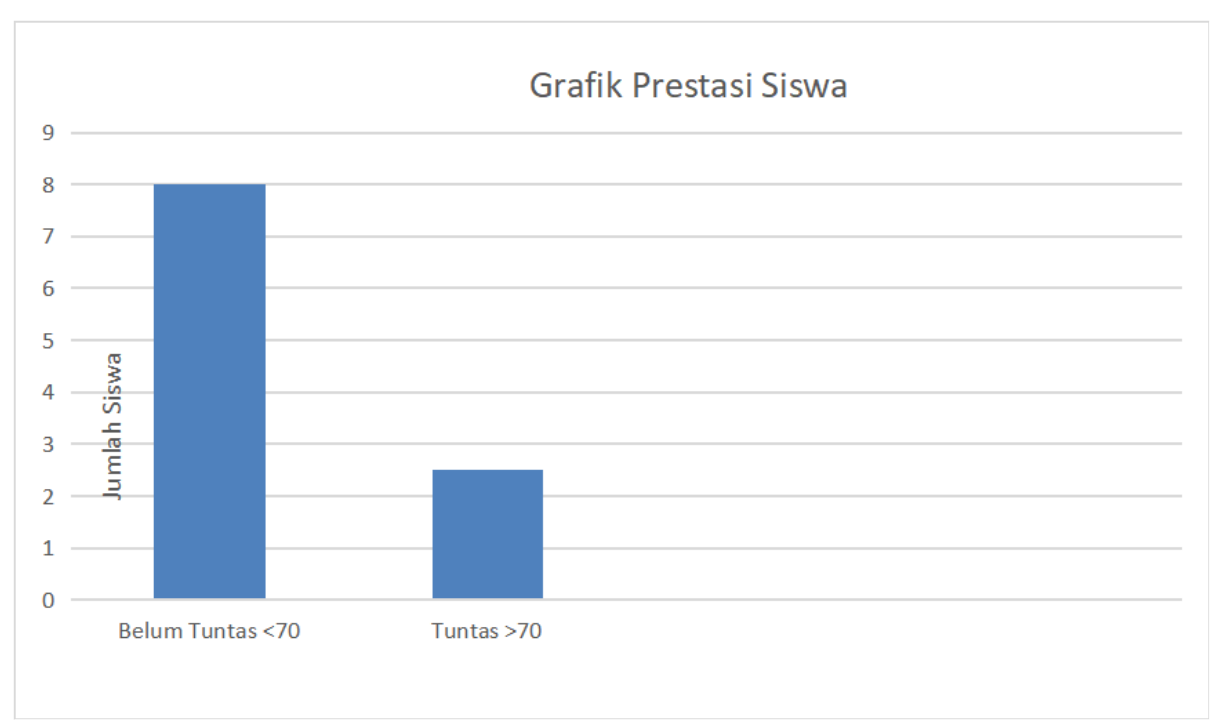

Gambar 1. Grafik Prestasi Siswa

Dari hasil pengamatan Peneliti ternyata Peningkatan Hasil Belajar Bahasa Indonesia Pada Materi Tokoh dan Penokohan Melalui Problem Based Learning (PBL) Pada Siswa Kelas IV SDN 01 Banjaranyar Tahun Pelajaran 2020/2021" ini bisa dikatakan mempunyai pengaruh terhadap hasil belajar siswa. Dari 15 siswa terdapat 7 siswa tuntas dalam hasil belajarnya atau $47 \%$ dan 8 siswa belum tuntas hasil belajarnya atau $53 \%$ Akan tetapi perlu diperbaiki pada saat proses evaluasi. Pada tahap ini peneliti menilai bahwa peserta didik kurang diberikan waktu yang cukup dalam mengerjakan. Berdasarkan refleksi pada siklus I maka diputuskan untuk melanjutkan ke siklus II dikarenakan belum mencapai ketuntasan klasikal yang diharapkan. Siklus II membahas materi selisih dua bilangan cacah pada soal cerita. Pembelajaran dengan model PBL dilaksanakan dengan 5 langkah PBL secara berurutan seperti siklus I. Yaitu siswa menyelesaikan masalah yang disajikan. Berikut ini adalah hasil belajar peserta didik pada siklus II yang bisa dilihat pada tabel berikut.

Tabel 2. Prestasi Belajar Siklus II

\begin{tabular}{lll}
\hline NILAI & JUMLAH SISWA & PROSENTASE \\
\hline tuntas $>70$ & 12 & $80 \%$ \\
\hline Belum Tuntas $<70$ & 3 & $20 \%$ \\
\hline
\end{tabular}




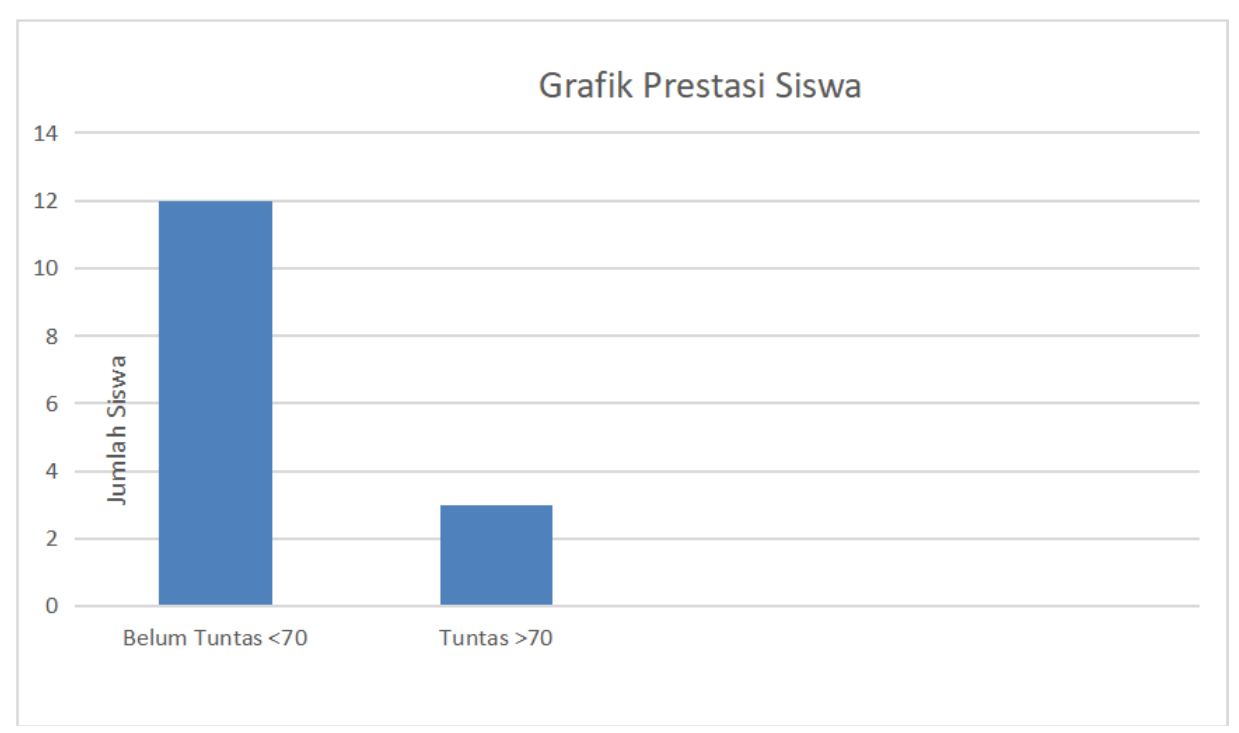

Gambar 2. Grafik Prestasi Siswa Siklus I

Ketuntasan klasikal mengalami peningkatan, pada siklus 2 terdapat 12 anak yang sudah tuntas dengan Kriteria Ketuntasan Minimal (KKM) sebesar 70. Persentase ketuntasan klasikalnya meningkat, jika pertemuan 1 hanya $47 \%$ maka pada pertemuan 2 menjadi $80 \%$.

Dari dua siklus yang sudah dilaksanakan selama 2 pertemuan dapat dipastikan bahwa model pembelajaran PBL dapat meningkatkan hasil belajar peserta didik pada

Mupel Bahasa Indonesia Kelas IV di SDN 01 Banjaranyar. Hal ini sesuai dengan konsep atau teori yang diungkap oleh Nanang Hanafiah dan Cucu Suhana (2009:30) bahwa langkah penerapan Model pembelajaran ini merupakan model pembelajaran inovatif yang melibatkan pemecahan masalah dimana peserta didik bekerja secara mandiri dalam mengkonstruksi pembelajarannya dan mengkulminasikannya dalam pemecahan masalah. Memang benar adanya dengan model PBL peserta didik akan membangun sendiri pengetahuannya dengan memecahkan masalah yang disajikan dalam soal yang diberikan. Peserta didik dapat memahami tokoh dan penokohan dengan tepat

\section{SIMPULAN}

Penerapan model pembelajaran Problem Based Learning (PBL) dapat meningkatkan hasil belajar peserta didik Kelas IV pada mupel Bahasa Indonesia materi tokoh dan penokohan. Peningkatan yang terjadi karena adanya kesan pembelajaran yang mendalam dari peserta didik tehadap materi yang diajarkan melalui setiap pemecahan masalah yang disajikan dalam soal. Peserta didik akan selalu teringat akan materi yang diajarkan dikarenakan mereka menemukan dan membangun sendiri pengetahuan mereka pada saat

menyelesaikan masalah yang disajikan. Berdasarkan penelitian yang telah dilaksanakan salah satu model pembelajaran yang harus dikuasai guru adalah PBL karena model ini sangat cocok digunakan dalam keadaan pandemi seperti ini, apalagi dalam kondisi belajar dari rumah. Peserta didik akan membangun pengetahuannya sendiri dengan pemecahan masalah yang membuat siswa berfikir kritis. Guru bisa memantau proses selama siswa menemukan jawaban dari permasalahan yang disajikan dan dilaksanakan dengan bekerja sama dengan orang tua. 
DAFTAR PUSTAKA

Arends, R. (2008). Learning to Teach, Terjemahan oleh Helly Prajitno \& Sri Mulyani. New York: McGraw Hill Company.

Eni Wulandari, Setyo Budi \& Kartika Chryati. (2013). Penerapan Model PBL pada Pembelajaran IPA Siswa Kelas V SD. Jurnal Kalam Cendekia PGSD Kebumen, 2 (1): 13-17.

Fogarty, R. (2009). How to Integrate the Curricula (Third Edition). Thousand Oaks, California: Corwin

I Gede Agus Siswantara, I.B. Surya Manuaba \& I Gede Mater (2013). Penerapan Model Problem Based Learning (PBL) Untuk Meningkatkan Aktivitas dan Hasil Belajar IPA Siswa Kelas IV SD Negeri 8 Kesiman. Jurnal Garuda Portal 1(1):110.

Kemendikbud. (2014). Materi Pelatihan Guru Implementasi Kurikulum 2013 Tahun 2014. Jakarta: Badan Pengembangan Sumber Daya Manusia Pendidikan dan Kebudayaan dan Penjaminan Mutu Pendidikan - Kementerian Pendidikan dan Kebudayaan.

Mawardi. (2014). Pemberlakuan Kurikulum SD/MI tahun 2013 dan Implikasinya terhadap Upaya Memperbaiki Proses Pembelajaran Melalui PTK. Scolaria: Jurnal Pendidikan dan Kebudayaan, 4(3), 107-121.

Muhammad Yaumi \& Muljono Damopolli. (2014).Action Research: Teori, Model,dan Aplikasi.Jakarta: Kencana Prenada Group.

Riska Apriani. (2013). Peningkatan Pembelajaran Perubahan Lingkungan melalui Model Problem Based Learning pada Siswa kelas IV SD Negeri Randugunting 3KotaTegal. Semarang: UNNES

Suharsimi Arikunto,Suhardjono \& Supardi. (2010). Penelitian Tindakan Kelas. Jakarta: Bumi Aksara.

Zubaidah, S. \& Corebima Aloysius, D. (2015). Asesmen Berpikir Kritis Terintegrasi Tes Essay. Tersedia di : https://www.researchgate.net/publication/322315188 